\title{
Editorial: COVID-19 Pandemic and the Case for Research on Traditional Management Accounting Practices
}

\author{
V. G. Sridharan ${ }^{\mathrm{a}}$, Michael S. C. Tse ${ }^{\mathrm{b}}$ \\ ${ }^{a}$ Adelaide Business School, The University of Adelaide, Australia \\ ${ }^{\mathrm{b}}$ Institute of Certified Management Accountants, Australia
}

Year 2020 has been an unexpectedly challenging year for the world. Despite the on-going US-China trade war, the outlook of global economy was positive at the end of 2019. However, the COVID-19 pandemic has plunged the world into the worst economic crisis of the century.

The COVID-19 pandemic has major implications to the business community. The lockdowns and other restrictions to physical activities has forced businesses to adapt their operations. For example, working from home and click and mortar business model has evolved to be the new normal for many businesses.

Furthermore, the pandemic has also exposed the weaknesses of the foundations upon which contemporary business models are designed. For example, the lean manufacturing system is grounded on the assumption that though on-demand supply chain can be physically established, it can be virtually controlled and therefore reliably maintained. However, the disruptions of global supply chains observed in 2020 clearly exposes the vulnerability of the system.

As observed in Laing (2018), management accounting researchers tend to focus on "contemporary" or "cutting edge" management accounting practices such as Activity-Based Costing and Balanced Scorecard. Research on "traditional" management accounting practices such as inventory cost methods (e.g., absorption versus variable costing or joint versus by-product cost allocation) or decision techniques (e.g., irrelevant sunk cost or relevant opportunity cost) is very limited (see Dillon \& Nash, 1978; Roodhooft \& Warlop, 1999). The lack of interest in research on traditional management accounting practices is apparently based on the belief that traditional management accounting practices are already well- 
researched and new studies on the area would add limited value to the body of knowledge.

However, such belief does not take the fact that prior studies on traditional management accounting practices have been conducted under the then-prevailing business environment into account. Management accounting, by nature, is highly context specific. The current business environment has significant impact on the relevance of management accounting practices to today's organisations. As such, the insights from prior studies that are conducted decades ago, may not be readily replicable into today's organisations that operate under different business environment. Furthermore, opportunities for new extensions of the already well-established concepts are often ignored (e.g., Gupta, Pevzner \& Seethamraju, 2010; Sun, Lan \& Liu, 2014; Winsen \& Stefano, 1979), which lead to a lop-sided growth of the discipline to the disregard of its substantive overall growth. Afterall, inventory costing and standard costing techniques remain central in most of the contemporary organisations today.

The editorial team of Management Accounting Frontiers believes that it is beneficial to conduct more investigation into traditional management accounting practices under contemporary business environment. While originality and current trend can be important guidelines for directing new research themes, it is equally important to contribute further so as to expand the time-tested and widely prevalent management accounting concepts. The editorial team identifies three important ways to contribute in this direction: 1) Theoretically sound replications of prior studies can add value to the body of knowledge if they can advance our understanding of established management accounting practices under the current environment; 2) Normative works that provide new insights on traditional management accounting practices under contemporary business environment; 3) New empirical (survey or experimental) studies into timetested concepts can also make valuable contribution to the body of knowledge.

We welcome new research that expands the frontiers of the traditional and entrenched management accounting research. 


\section{References}

Dillon, R. D. and Nash, J. F., (1978), "The True Relevance of Relevant Costs", The Accounting Review, Vol. 53 No. 1, pp.11-17.

Laing, G. K., (2018), "Seismic Measurement of Management Accounting Innovations: Using the Scale of Innovation Intensity", Management Accounting Frontiers, Vol. 1, pp. 3-14.

Gupta, M., Pevzner, M. and Seethamraju, C., (2010), "The Implications of Absorption Cost Accounting and Production Decisions for Future Firm Performance and Valuation", Contemporary Accounting Research, Vol. 27 No. 3, pp. 889-922.

Roodhooft, F. and Warlop, L., (1999), "On the Role of Sunk Costs and Asset Specificity in Outsourcing Decisions: A Research Note", Accounting, Organizations and Society, Vol. 24 No.4, pp. 363-369.

Sun, J., Lan, G. and Liu, G. (2014), "Independent Audit Committee Characteristics and Real Earnings Management", Managerial Auditing Journal, Vol. 29 No.2, pp. 153-172.

Winsen, J. K. and Stefano, A. D., (1979), "A Note on the Possibility of Income Manipulation through the Absorption of Fixed Overhead", Accounting and Finance, Vol. 19 No. 2, pp. 1-90. 
Management Accounting Frontiers 3 (2020) 1 - 4 